\title{
Correction to: The relationship between plant growth and water consumption: a history from the classical four elements to modern stable isotopes
}

\author{
Oliver Brendel ${ }^{1}$
}

Received: 4 June 2021 / Accepted: 4 June 2021 / Published online: 17 June 2021

(C) The Author(s) 2021

\section{Correction to: Annals of Forest Science} https://doi.org/10.1007/s13595-021-01063-2

The article, The relationship between plant growth and water consumption: a history from the classical four elements to modern stable isotopes, written by Oliver Brendel, was originally published electronically on the publisher's internet portal on 28 April 2021 without open access. With the author(s)' decision to opt for Open Choice, the copyright of the article changed on 3 June 2021 to $($ C) The Author(s) 2021 and the article is forthwith distributed under a Creative Commons Attribution CC BY 4.0 International License, which permits use, sharing, adaptation, distribution, and reproduction in any medium or format, as long as you give appropriate credit to the original author(s) and the source, provide a link to the Creative Commons licence, and indicate if changes were made. The images or other third party material in this article are included in the article's Creative Commons licence, unless indicated otherwise in a credit line to the material. If material is not included in the article's Creative Commons licence and your intended use is not permitted by statutory regulation or exceeds the permitted use, you will need to obtain permission directly from the copyright holder. To view a copy of this licence, visit http// creativecommons.org/licenses/by/4.0.

Publisher's note Springer Nature remains neutral with regard to jurisdictional claims in published maps and institutional affiliations.
Handling Editor: Andrew Merchant.

The original article can be found online at https://doi.org/10.1007/ s13595-021-01063-2.

Oliver Brendel

oliver.brendel@inrae.fr

1 Université de Lorraine, AgroParisTech, INRAE, UMR Silva, Nancy, France 